\title{
A study of serum magnesium level in hypothyroid cases in a tertiary care hospital, Perambalur
}

\author{
Vijayapriya I. ${ }^{1 *}$, Saravanan $\mathrm{S}^{2}$
}

DOI: https://doi.org/10.17511/ijmrr.2019.i03.08

\footnotetext{
1* I. Vijayapriya, Assistant Professor, Department of Biochemistry, Government Head Quarters Hospital, Perambalur, Tamilnadu, India.

2 S. Saravanan, Senior Civil Surgeon, Government Head Quarters Hospital, Perambalur, Tamilnadu, India.
}

Magnesium is an incredibly vital mineral found in the human body. Magnesium clearly affects the entire body and naturally will interact with thyroid functions, both directly and indirectly. Objectives: To assess the levels of serum magnesium in patients with hypothyroidism and its correlation with TSH levels. Methodology: An observational study consists of 174 cases of hypothyroidism were selected. All patients with hypothyroidism, newly diagnosed with age above 18 years were included, all patients with malignancy, multiple endocrine disorder, CKD and patients supplemented with minerals were excluded in the study. Thyroid function and serum magnesium levels were done and analyzed in these patients. Results: In our study mean serum magnesium level in hypothyroid cases was $2.18 \pm 0.02 \mathrm{mg} / \mathrm{dl}$. Our study done with a follow up of thyroid function and serum magnesium level in hypothyroidism after supplementation with thyroid hormone and diet supplementation for magnesium showed a significant improvement which reciprocate the incidence of hypo magnesium in hypothyroidism and which is inversely proportionate to TSH levels which was not statistically significant. Conclusion: The alteration of serum magnesium level in hypothyroidism was not established in our study statistically.

Keywords: Serum magnesium, Hypothyroidism, Thyroid function test

Corresponding Author

I. Vijayapriya, Assistant Professor, Department of Biochemistry, Government Head Quarters Hospital, Perambalur, Tamilnadu, India.

Email: drvijayapriya@gmail.com
How to Cite this Article

To Browse

Vijayapriya I, Saravanan S. A study of serum magnesium level in hypothyroid cases in a tertiary care hospital, Perambalur. Int J Med Res Rev. 2019;7(3):195-199.

Available From

https://ijmrr.medresearch.in/index.php/ijmrr/article/ view/1058

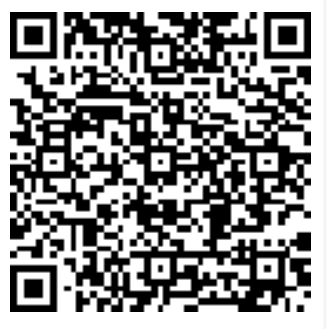

Manuscript Received 2019-05-10

Conflict of Interest No

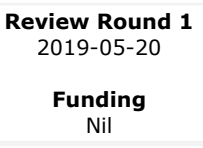

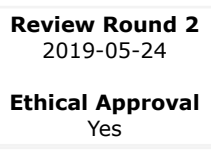

Accepted 2019-05-28

Note

(c) 2019 by I. Vijayapriya, S. Saravanan and Published by Siddharth Health Research and Social Welfare Society. This is an Open Access article licensed under a Creative Commons Attribution 4.0 International License https://creativecommons.org/licenses/by/4.0/ unported [CC BY 4.0]. 


\section{Introduction}

Dysfunction and anatomic abnormalities of the thyroid are among the most common diseases of endocrine glands [1]. Hypothyroidism is one of the most common forms of thyroid dysfunction resulting from the deficiency of thyroid hormones or from their impaired activity [2]. Hypothyroidism is ten times more common in women than men and its prevalence increase with age [3]. Biochemically decrease in T3 and T4 concentration leads to hyper secretion of pituitary TSH and an amplified increase in serum TSH levels. This is a key laboratory finding in diagnosis of hypothyroidism [4].

Thyroid hormones perform a wide array of metabolic functions including regulation of lipids, carbohydrates, protein and electrolytes and mineral metabolism [5]. Mineral metabolisms like calcium, magnesium and phosphorous is frequently disturbed in thyroid dysfunctions. Thyroid hormones exert its effects on osteoblasts via nuclear receptors to stimulate osteoclastic bone resorption [6]. Thyroid hormones probably stimulate bone resorption directly, thereby increasing serum calcium and phosphorous concentrations and also suppressing serum parathyroid hormone and 1,25-dihydroxy vitaminD3 concentrations. The decrease in these bone-resorbing hormones limits further increase in serum calcium concentration but also results in enhanced intestinal calcium absorption. In adult hypothyroidism the opposite effects are seen [7].

Although the changes in analytes, including magnesium and calcium may be slight in thyroid disease, it is possible that these disturbances will be important for a patient in long term. Recently, it has been suggested that some of metabolic disorders, hypertension and cardiovascular disease are linked by common defects in metabolism of divalent cations such as calcium and magnesium. The exact mechanism underlying these relationships is not fully understood, potential mechanism is the basic role of these cations in metabolic pathways [8].

Indian patients are different from western patients from bone mineral homeostasis point of view. On one hand, thyroid disorders are most common prevalent conditions and on the other hand, Indian studies focusing on the blood levels of calcium \& phosphorous in thyroid disorders are sparse [6]. The present study was undertaken to assess the alterations in the levels of serum magnesium total in patients with hypothyroidism.
We also investigated the correlation between TSH levels and the serum concentration of the above mineral.

\section{Methodology}

Type of study and setting: This study was a hospital based multicentric study conducted at Biochemistry department, Internal medicine department, DSMCH, and OP department of GH, Perambalur, between 2016 and 2019.

Sampling method: An observational study consists of 174 cases of hypothyroidism were selected.

Sample collection: Blood Sample Collection- A 3ml of venous blood was drawn from each volunteer using a disposable plain vaccutainer system in fasting condition. Serum was separated within half an hour by centrifugation and stored at $2-8^{\circ} \mathrm{C}$ temperature till analysis was done. After written consent for enrollment in the study, a detailed history was taken from all the subjects along with a detailed clinical examination.

Analysis of Sample: Serum T3, T4 and TSH were measured by MAGLUMI 1000 Chemi Luminescent Immuno Assay. Serum magnesium total was estimated by Calmagite method on Erba 320 fully automated analyzer using commercially available kits. Inclusion criteria: All patients with hypothyroidism newly diagnosed with age above 18 years. Exclusion criteria: All patients with malignancy, multiple endocrine disorder, CKD and patients supplemented with minerals. Statistical method: Data are expressed as Mean \pm S.D. Correlation between parameter was studied by Pearson's correlation coefficient using Graph Pad statistical software.

\section{Results}

Table-1: Age and Sex wise Distribution.

\begin{tabular}{|l|l|l|l|l|}
\hline \multirow{2}{*}{ Age } & \multicolumn{2}{|c|}{ Sex } & \multicolumn{1}{c|}{ No of Patients } & \multirow{2}{*}{$\%$} \\
\cline { 2 - 4 } & Male & Female & & \\
\hline Below 20 & & 05 & 05 & 2.87 \\
\hline $21-30$ & 10 & 47 & 57 & 32.75 \\
\hline $31-40$ & 11 & 47 & 58 & 33.33 \\
\hline $41-50$ & 08 & 25 & 33 & 18.96 \\
\hline $51-60$ & 07 & 07 & 14 & 8.04 \\
\hline$>60$ & 04 & 03 & 07 & 4.02 \\
\hline Total & 40 & 134 & 174 & $100 \%$ \\
\hline
\end{tabular}

A total of 174 cases were studied. 
Among the cases 40 (22.98\%) were male and 134 (77.01\%) were female. There were more females than males among cases. The maximum number of patients were in the age group between $21-40$ years age $(>65 \%)$.

Table-2: Baseline characteristics of cases.

\begin{tabular}{|l|l|l|}
\hline \multicolumn{2}{|c|}{ Mean age } & \multicolumn{1}{c|}{$39.23 \pm 6.74$} \\
\hline Mean BP & Systolic & $103.2 \pm 2.37$ \\
\cline { 2 - 3 } & Diastolic & $72.6 \pm 1.98$ \\
\hline Mean PR & $81.2 \pm 1.24$ \\
\hline Mean HT & $154 \pm 2.43$ \\
\hline Mean Wt & $52.45 \pm 1.98$ \\
\hline Mean & \\
T3 $(\mathrm{ng} / \mathrm{ml})$ & $0.4832 \pm 0.027$ \\
T4 $(\mu \mathrm{g} / \mathrm{dl})$ & $4.9349 \pm 0.738$ \\
TSH $(\mu \mathrm{IU} / \mathrm{ml})$ & $39.447 \pm 3.143$ \\
\hline Mean magnesium $(\mathrm{mg} / \mathrm{dl})$ & $2.18 \pm 0.02$ \\
\hline
\end{tabular}

In our present study the mean age was $39.23 \pm 6.74$. In the present study the mean pulse rate was $81.2 \pm 1.24$. The mean systolic and diastolic blood pressure was $103.2 \pm 2.37$ and $72.6 \pm 1.98$ $\mathrm{mmHg}$. The mean height and weight were $154 \pm 2.43$ $\mathrm{cm}$ and $52.45 \pm 1.98 \mathrm{~kg}$ respectively. In the present study the mean TSH was $39.447 \pm 3.143 \mu I U / m l$. The mean magnesium was $2.18 \pm 0.02 \mathrm{mg} / \mathrm{dl}$.

Table-3: Serum Magnesium level in relationship with TSH.

\begin{tabular}{|l|l|l|}
\hline S. No & \multicolumn{1}{|c|}{ TSH level } & \multicolumn{1}{c|}{ Mean Serum Magnesium level } \\
\hline 1 & $<0.4$ & \\
\hline 2 & $0.4-4.5$ & $1.9 \pm 0.01(1)$ \\
\hline 3 & $4.5-10$ & $1.98 \pm 0.02(44)$ \\
\hline 4 & $>10$ & $1.87 \pm 0.01(129)$ \\
\hline
\end{tabular}

In the present study the mean serum magnesium level was $1.87 \pm 0.01 \mathrm{mg} / \mathrm{dl}$ in patients with a TSH value of $>10 \mu I U / \mathrm{ml}$. The mean serum magnesium level was $1.98 \pm 0.02 \mathrm{mg} / \mathrm{dl}$ in patients with a TSH value of $4.5-10 \mu \mathrm{IU} / \mathrm{ml}$.

Table-4: Serum Magnesium level in relationship with $\mathbf{T 3}$.

\begin{tabular}{|l|l|l|}
\hline S. No & \multicolumn{1}{|c|}{ T3 level } & \multicolumn{1}{c|}{ Mean Serum Magnesium level } \\
\hline 1 & $0.1-0.5$ & $1.79 \pm 0.21(94)$ \\
\hline 2 & $0.6-2.5$ & $1.98 \pm 0.3(80)$ \\
\hline 3 & $>2.5$ & - \\
\hline
\end{tabular}

In the present study the mean serum magnesium level was $1.79 \pm 0.21 \mathrm{mg} / \mathrm{dl}$ in patients with a T3 value of $0.1-0.5 \mathrm{ng} / \mathrm{ml}$. The mean serum magnesium level was $1.98 \pm 0.03 \mathrm{mg} / \mathrm{dl}$ in patients with a $T 3$ value of $0.6-2.5 \mathrm{ng} / \mathrm{ml}$.

Table-5: Serum Magnesium level in
relationship with T4
\begin{tabular}{|l|l|l|}
\hline S. No & T4 level & \multicolumn{1}{|c|}{ Mean Serum Magnesium level } \\
\hline 1 & $0.1-5.0$ & $2.1 \pm 0.21(95)$ \\
\hline 2 & $5.1-13.0$ & $1.98 \pm 0.22(78)$ \\
\hline 3 & $>13$ & $1.8 \pm 0.12(1)$ \\
\hline
\end{tabular}

In the present study the mean serum magnesium level was $2.1 \pm 0.21 \mathrm{mg} / \mathrm{dl}$ in patients with a T4 value of $0.1-5.0 \mu \mathrm{g} / \mathrm{dl}$. The mean serum magnesium level was $1.98 \pm 0.22 \mathrm{mg} / \mathrm{dl}$ in patients with a T4 value of $5.1-13.0 \mu \mathrm{g} / \mathrm{dl}$.

Table-6: Mean levels in beginning and six month follow up study $(n=36)$.

\begin{tabular}{|l|l|l|l|}
\hline Investigation & $\begin{array}{c}\text { Beginning of our } \\
\text { study levels }(\mathrm{n}=36)\end{array}$ & $\begin{array}{l}\text { Six month follow } \\
\text { up levels }(\mathrm{n}=36)\end{array}$ & P value \\
\hline Mean T3 $(\mathrm{ng} / \mathrm{ml})$ & $0.632 \pm 0.02$ & $0.78 \pm 0.027$ & $\begin{array}{l}\mathrm{p}=0.043 \\
(\mathrm{p}<0.01)\end{array}$ \\
\hline Mean T4 $(\mu \mathrm{g} / \mathrm{dl})$ & $4.9 \pm 0.2$ & $6.132 \pm 0.2$ & $\begin{array}{l}\mathrm{p}=0.008 \\
(\mathrm{p}<0.001)\end{array}$ \\
\hline $\begin{array}{l}\text { Mean TSH } \\
(\mu \mathrm{IU} / \mathrm{ml})\end{array}$ & $38.55 \pm 1.42$ & $4.55 \pm 0.32$ & $\begin{array}{l}\mathrm{p}=0.000732 \\
(\mathrm{p}<0.0001)\end{array}$ \\
\hline $\begin{array}{l}\text { Mean } \\
\text { magnesium level } \\
(\mathrm{mg} / \mathrm{dl})\end{array}$ & $1.647 \pm 0.012$ & $1.849 \pm 0.02$ & $\begin{array}{l}\mathrm{p}=0.0651 \\
(\mathrm{p}<0.01)\end{array}$ \\
\hline
\end{tabular}

In the present study the mean magnesium level was $1.647 \pm 0.012$ and after a regular follow up and adequate replacement of thyroid hormone the follow up mean magnesium was $1.849 \pm 0.02$ which was not statically significant.

\section{Discussion}

Magnesium is an incredibly vital mineral found in the human body. Sadly other minerals like calcium and iron tend to take the spotlight, leaving many adults oblivious to how important magnesium is. Magnesium plays an important role in a wide range of body functions. Over 300 different enzyme systems within the body rely on magnesium to function properly. Magnesium performs double-duty when it comes to this process.

Not only does magnesium stimulate the thyroid gland to produce more T4, but it simultaneously changes T4 into T3. This is a huge reason why magnesium is so vital. There is also a strong correlation between magnesium and the development of goiter. Important nutrient in preventing goiter is iodine, but magnesium is right there helping too. Magnesium helps you to make more $\mathrm{T} 4$ in the thyroid gland. 
Without magnesium, many of the thyroid enzymes that make thyroid hormone simply could not function Thyroid hormone is a central regulator of body hemodynamics, thermoregulation and metabolism.

Therefore, it has an influence on renal hemodynamics, glomerular filtration and electrolyte handling [9]. Thyroid hormone affects the glomerular filtration rate and blood flow and has a direct effect on $\mathrm{Ca}$ and $\mathrm{Mg}$ resorption [10]. Total magnesium levels in serum were' found to be significantly lowered in hypothyroid patients. Thyroid hormone is essential for normal growth and maturation of the skeleton.

In hypothyroidism there is a depressed turnover due to impaired mobilization of calcium into the bone that leads to decrease blood calcium level. In hypothyroidism there is hypomagnesaemia because of urinary output and fractional excretion of magnesium through urine. Magnesium level is reduced due to influence on GFR and decreased clearance. In hypothyroidism there is an increased renal blood flow leading to high clearance of magnesium from the kidneys.

With the above evidence our study was focused on estimation of serum magnesium level in hypothyroidism. In our study the mean age was $39.23 \pm 6.74$ years which was similar to a study done by Mukesh $G$ Gohel et al (14) showed a mean age of $46.7+7.3$ years. Our study showed mean serum magnesium $2.18 \pm 0.02 \mathrm{mg} / \mathrm{dl}$, which was normal range in respect to reference in hypothyroidism. Other study ranges are

\begin{tabular}{|l|l|l|}
\hline \multicolumn{1}{|c|}{ Study } & Serum Magnesium(mg/dl) & \multicolumn{1}{|c|}{ Comment } \\
\hline In present study & $2.18 \pm 0.02$ & $\begin{array}{l}\text { Negative } \\
\text { correlation }\end{array}$ \\
\hline $\begin{array}{l}\text { Mukesh G Gohel et al } \\
{[12]}\end{array}$ & $1.36+0.49$ (hypothyroidism) & $\begin{array}{l}\text { Positive } \\
\text { correlation }\end{array}$ \\
\hline Kavitha MM et al [13] & $\begin{array}{l}2.37+0.46(\text { overt } \\
\text { hypothyroidism) }\end{array}$ & $\begin{array}{l}\text { Positive } \\
\text { correlation }\end{array}$ \\
\hline Mane AY et al [11] & $2.21 \pm 0.29$ & $\begin{array}{l}\text { Positive } \\
\text { correlation }\end{array}$ \\
\hline Arvind Bharti et al [14] & $2.28 \pm 0.27$ & $\begin{array}{l}\text { Oositive } \\
\text { correlation }\end{array}$ \\
\hline Susanna et al [15] & $1.88 \pm 0.15$ & $\begin{array}{l}\text { Negative } \\
\text { correlation }\end{array}$ \\
\hline
\end{tabular}

Lower serum magnesium level in hypothyroid patients is due to impaired magnesium homeostasis [11]. Our study done with a follow up of thyroid function and serum magnesium level in hypothyroidism after supplementation with thyroid
Hormone and diet supplementation for magnesium showed a significant improvement which reciprocate the incidence of hypo magnesium in hypothyroidism and which is inversely proportionate to TSH levels which was not statistically significant.

\section{Conclusion}

In our study done to estimate the serum magnesium level in hypothyroidism in south India did not reveal a statistical significant lower value of serum magnesium levels. The present study showed negative correlation with normal range of serum magnesium levels in patients with hypothyroidism. The present study signifies no need of supplementing magnesium of any sources. The ideal modality is to have an adequate maintenance of TSH with adequate dose of thyroid supplementation will not affect the magnesium levels.

\section{Reference}

01. P Reed, Terry FD, Martin JS, Ian DH. Thyroid physiology and diagnostic evaluation of patients with thyroid disorders, In- Henry MK, Shlomo M, Kenneth SP, P Reed, editors, Williams Textbook of Endo-crinology. 11th ed, PhiladelphiaSaunders Elsevier. 2008;1002.

[Crossref]

02. Taylor PK. Thyroid disease- Hypothyroidism and Goitre. Medicine Update. 1993;1;357-356. [Crossref]

03. Vanderpump MP. The epidemiology of thyroid disease. Br Med Bull. 2011;99;39-51.

doi: $10.1093 / \mathrm{bmb} / \mathrm{Idr030}$ [Crossref]

04. Galesanu C, Linsic N, Teslaru R, Apostu L, Zbranca $E$. Lipid profile in a group of hypothyroid patients vs treated hypothyroid patients. Rev Med Chir Soc Med Nat Lasi. 2004;108(3)554-560.

[Crossref]

05. Pearce EN. Hypothyroidism and dyslipidemiamodern concepts and approaches. Curr Cardiol Rep. 2004 Nov;6(6)451-6.

[Crossref]

06. Shivaleela MB, Poornima RT, Jayaprakash MDS. Serum Calcium and Phosphorous levels in thyroid dysfunction. Indian Journal of Fundamental and Applied Life Sciences. 2012;2(2)179-183.

[Crossref] 
07. Auwerx J, Bouillon R. Mineral and bone metabolism in thyroid disease- a review. Q J Med. 1986 Aug;60(232)737-52.

[Crossref]

08. Abbas MM, Mahmoud $\mathrm{AH}$ and El-Desouky W. Biochemical Changes in Serum Lipid Fractions, Calcium, Magnesium and Phosphorous Levels in Women with Subclinical Hypothyroidism. Nature and Science. 2013;11(5)113-118.

[Crossref]

09. Laura HM, Jeffrey SB. The Renal Manifestations of Thyroid Disease. J Am Soc Nephrol. $2012 ; 23 ; 22-26$.

[Crossref]

10. McCaffrey C, Quamme GA. Effects of thyroid status on renal calcium and magnesium handling. Can J Comp Med. 1984 Jan;48(1)517.

[Crossref]

11. Mane AY, Bhagwat VR. Assessment of some biochemical markers of bone turnover in thyroid dysfunction state. International Journal of Pharma and Bio Sciences. 2012;3(3)B126-133. [Crossref]
12. Mukesh G Gohel, Aashka M Shah, Akash M Shah, Jemil S Makad. A Study of Serum Calcium, Magnesium and Phosphorous Level in Hypothyroidism Patients. Int J Mcd Helliih Sci. Oct $2014 ; 3(4)$.

[Crossref]

13. Kavitha MM, Chandrashekharyya SH, SV Kashinakunti, Sunitha H, Neela BM, Sanjeev Ratna. Alteration in levels of Serum calcium, phosphorous and magnesium in patients of Hypothyroidism. Int Bioi Med Res. 2014;5(4)4594-4596.

[Crossref]

14. Arvind Bharti, Shailaza Shrestha, Rahul Rai, Mukesh Kumar Singh. Assessment of serum minerals and electrolytes in thyroid patients. International Journal of Advances in Scientific Research. 2015;1(06)259-263.

[Crossref]

15. Susanna TY, Sagayaraj A, Shashidharkn, Gomathi M, Mahesh V. A correlative study of thyroid profile and mineral status in patients with hypothyroidism - a hospital based case control study. Asian $j$ pharm clin res. 9(3)2016;292-294.

[Crossref] 